\title{
Assessing the Success of a Mentoring Program for Academic Librarians
}

\author{
Karen Harker, Setareh Keshmiripour, Marcia McIntosh, Erin O'Toole, and Catherine \\ Sassen \\ University of North Texas, USA
}

\begin{abstract}
A continuous cycle of assessment contributes to the success of a mentoring program, as illustrated in this case study from a large academic library. The Mentoring Competencies Assessment, the Fear of Negative Evaluation Scale, a satisfaction survey, and a focus group are used to assess the program. The assessment results indicate that the program is meeting its goals of facilitating the professional development of protégés, improving mentor competencies, increasing the confidence of participants, and expanding future participation in the program.
\end{abstract}

\section{Introduction}

Assessment contributes to the effectiveness, relevance, and sustainability of a mentoring program. Lunsford identifies several reasons for evaluating a mentoring program. ${ }^{1}$ First, assessment provides unbiased information about adjustments needed in the program. Additionally, assessment information identifies how resources should be allocated to improve the program. Furthermore, assessment results can be shared with participants, potential participants, and stakeholders to emphasize the success of the program. Sharing assessment information with administrators may be a significant factor in securing program funding and time allowed for participants. Assessment also is needed to track the implementation of the mentoring program's plans and goals. ${ }^{2}$

The assessment of many faculty development programs is limited to participant satisfaction. ${ }^{3}$ Although this measure could be used to address areas of dissatisfaction, it is limited in its scope. Little attempt is made to determine the impact of the program on the participants' abilities, skills, and future careers.

\section{Literature Review}

Surprisingly few academic libraries provide mentoring for junior librarians who face challenging requirements in scholarship and service to achieve promotion and tenure, and even fewer assess their mentoring programs. Goodsett and Walsh distributed a survey via professional Listservs to explore how mentoring programs help librarians achieve tenure. ${ }^{4}$ Of the 60 responding librarians who had mentoring programs at their libraries, all reported that their programs were not assessed. The survey results are consistent with the findings of an earlier scoping review of mentoring literature from academic libraries conducted by Lorenzetti and Powelson. ${ }^{5}$ Of the 40 case studies reviewed, only 18 included assessment of mentoring activities. This review revisits the 18 case studies and extends to literature published between 2014 and 2018 about assessment of academic mentoring programs. The focus of the review is the quality of the program assessments and their contribution to the field of library assessment.

The majority of the case studies reviewed by Lorenzetti and Powelson describe assessment by the survey method. The coordinators of the mentoring programs were thorough in administering surveys to all participants, regardless of rank, tenure status, or role (mentor/protégé), in both dyad and peer mentoring programs. ${ }^{6}$ This is a strength of the surveys because measures of engagement and satisfaction of all participants are necessary for making improvements and winning administrative support for mentoring programs. A weakness of the survey instruments is the lack of testing for validity and reliability, which are characteristics valued in a rigorous survey method. ${ }^{7}$ The most serious weakness in the preponderance of case studies is the failure to include the survey instrument itself, or even the survey questions. Cirasella and Smale ${ }^{8}$ and Sapon-White et al. ${ }^{9}$ did append the survey instruments, making it possible for the library assessment community to peer-review the battery of questions and replicate the assessments. 
Two case studies identified by Lorenzetti and Powelson describe qualitative assessments of mentoring programs: interviews and round table discussions. ${ }^{10}$ Qualitative methods have the potential advantage over surveys of revealing a deeper understanding of participants' perspectives and development over a course of a program. These case studies have a paucity of details about how the assessments were conducted, which makes peer review and replication of the methods problematic. For instance, Kuyper-Rushing reports facilitating separate discussion groups, but the discussion questions are not provided in the case study. ${ }^{11} \mathrm{~A}$ more serious concern in both assessments is the lack of a safe space where participants could freely discuss their opinions. The coordinators of the mentoring programs at Louisiana State University ${ }^{12}$ and California State University, Long Beach ${ }^{13}$ facilitated the round table discussions and interviews respectively, rather than an impartial party. Their presence could have had an effect on the participants' discussion, resulting in responses that may have been less than candid and complete.

Ideally, assessment of a mentoring program should include both quantitative and qualitative methods, which can offset each other's strengths and limitations and provide triangulation. ${ }^{14}$ The remainder of the case studies that were reviewed by Lorenzetti and Powelson and included assessment achieve this balance by using mixed methods in assessing mentoring activities. ${ }^{15}$ However, these assessments suffer from the same weaknesses described earlier. Surveys were the most common quantitative evaluation used, but only one case study appended the instrument for peer review and replication. ${ }^{16}$ The case studies failed to report the questions asked at group discussions and interviews, and most indicated the administrators of the mentoring programs conducted the interactions, rather than facilitators who had no investment in the programs.

The more recent articles identified for this review are notable for how little they contribute to the academic library community's knowledge of how to assess mentoring programs. The search for publications from 2014 to 2018 revealed no new case studies of mentoring programs including assessment. Two surveys of sizeable populations of individual librarians and ARL libraries found that few libraries assess the success of their mentoring programs. ${ }^{17}$ Research about library mentorship is evolving from case studies to large-scale surveys, but three of these recent studies failed to include any questions about the assessment of mentoring programs. ${ }^{18}$

Rigorous assessment of mentoring programs is a challenge for academic librarians, who have limited time in which to learn, plan, implement, and thoroughly report qualitative and quantitative methods. Lack of time also affects librarians' ability to continually review mentoring programs, which is described in only one case study from 2009. ${ }^{19}$ This case study presents a model of mixed methods assessment that is rigorous and sustained, yet can be accomplished by busy academic librarians. The authors hope to contribute to the improved assessment of mentoring programs in academic libraries with this study and its accompanying instruments.

\section{Background}

This case study describes the assessment of a mentoring program for librarians at the University of North Texas (UNT) Libraries in Denton. UNT is the largest public university in the Dallas-Fort Worth area, with over 38,000 students. The UNT Libraries' cataloged holdings include seven million print and digital items housed in six facilities. The libraries employ approximately 55 librarians. UNT librarians have faculty status, but not faculty rank or tenure. They are eligible for service on the Faculty Senate and its committees. They also are eligible for research funds, development leave, and faculty awards. The librarians are evaluated annually on their assigned duties, scholarship, and service. They must meet evaluation criteria in all three areas to attain contract renewal and promotion.

The UNT Libraries' Mentoring Program was created in 2015. The mission of the program is to support librarians to be successful in their careers. The program includes mentor-protégé dyads, mentor training, and group mentoring facilitated by one senior librarian. Table 1 provides the demographics of the participants of the mentoring program during its first three years (FY 2015/16 through FY 2017/18). 
The Mentoring Program Workgroup administers the mentoring program. The workgroup is composed of librarians of all ranks from various divisions of the libraries. Workgroup members are appointed for staggered two-year terms. The current officers include two co-chairs, an assessment officer, a mentorship coordinator, and a secretary. The director of library administrative services is an ex-officio member of the workgroup. The authorship team of this paper is composed of current and former members of the workgroup.

The duties of the Mentoring Program Workgroup include managing the mentoring program and making recommendations for a budget. The workgroup also is responsible for assessing the program and making changes when appropriate.

The Mentoring Program Workgroup administers a continuous cycle of assessment with multiple measures and methods. The assessment instruments include the Mentoring Competencies Assessment, the Fear of Negative Evaluation survey, and the End of Program Evaluation. The workgroup also recently conducted a focus group composed of protégés in the mentoring program. Assessment measures address the goals of the mentoring program, which include facilitating the professional development of protégés, improving mentoring competencies, increasing confidence of participants, and expanding future participation in the program. The University of North Texas Institutional Review Board has approved all assessment instruments used by the workgroup.

\section{Assessments}

\section{Mentoring Competencies Assessment (MCA)}

The Mentoring Program Workgroup wanted to use valid and reliable methods for assessing the program's impact on the development of both protégés and mentors. The workgroup conducted a literature review and found a few case studies describing the evaluation of mentorship programs in libraries. The predominant measure reported was satisfaction with the program. ${ }^{20}$ The workgroup was able to find more evaluation resources after extending the literature review to include other disciplines.

Medical researchers developed the Mentoring Competencies Assessment (MCA) to assess a multiinstitutional program, the Clinical and Translational Science Awards (CTSA) Mentor Working Group. ${ }^{21}$ This program supported the training of mentors of young clinical researchers at 16 participating sites using a standard workshop curriculum and training manual. The instrument was developed in three phases based on an extensive literature review, alignment with the training curriculum and manual, and cognitive interviews to assess the cognitive validity of the instrument. The final version of the assessment instrument consisted of 26 items on a seven-point Likert-type scale asking the mentors to assess their own skills, and for mentees to assess the skills of their mentors. The items covered six categories of competencies:

- Maintaining effective communication

- Aligning expectations

- Assessing understanding

- Fostering independence

- Addressing diversity

- Promoting professional development

In the validation study, the mentors and the protégés took the assessment prior to the training, which was provided some time after the mentorship program had begun. The sample tested included 283 mentors and 283 protégés from 16 different institutions. The MCA was subjected to rigorous testing of reliability and construct validity, and it was found to be moderately reliable and have strong construct validity. ${ }^{22}$ The MCA is freely available from the University of Wisconsin. ${ }^{23}$

Because of the documented results of this rigorous validity testing, the MCA was chosen to assess the impact of training and support throughout the year for our mentors. While the instrument was developed for a program in a field wholly different from librarianship, the items were general enough to be applicable to 
most mentorship training programs. One item in the original MCA (related to setting research goals) was removed because it was not a priority for our new librarians.

The same assessment measures were used for each of the three years of the mentoring program at the UNT Libraries, from FY 2015/16 through FY 2017/18. All participants in these three years were professional librarians. Most of the protégés were new to academic librarianship, while the mentors had extensive experience in their specializations, in academic librarianship in general, and at the university library specifically. Mentors and protégés responded to the assessments in each year. Some individuals participated in the program during multiple years and responded to assessments in each of these years.

The MCA results discussed in this assessment are accumulated from three consecutive annual mentoring programs. The Mentoring Program Workgroup determined the mean and standard deviation, median, and mode for each of the 25 items ranked by mentors and protégés to measure mentors' competency levels. The workgroup also compared the ratings from the surveys taken at the beginning of the program (pre-test) with those taken at the end of the program (post-test). Because the surveys were sent anonymously, analysis could be conducted only at the group level and not at the individual participant level.

The mean scores for the skills assessed on the MCA, as rated by the mentors themselves, are between 4.75 and 5.85 pre-test, with the lowest score for "Setting clear mentoring relationship expectations" and the highest score for "Acknowledging protégé's professional contribution" (Table 2). After the mentoring program, the range of the scores for the skills changed to 3.18-6.18, with the lowest and highest scores for "Coordinating effectively with supervisor(s)" and "Establishing a trustful relationship," respectively. The mean score and standard deviation of mentors' ratings of most skills were higher in post-test, compared to their ratings in pre-test.

The range of mean scores for the skills in the pre-test, as rated by the protégés, is between 5.28 and 6.56 pretest, with the lowest and highest scores for "Helping protégé maintain work-life balance" and "Developing strategies to achieve goals," respectively (Table 3). The range of mean scores increased to 5.55-6.8 in the post-test. Similar to the ratings by their mentors, the mean scores assigned by protégés consistently increased in the post-test assessment. However, the standard deviation of the scores decreased (i.e., less variation in the post-test mean scores).

The mentors' ratings of their own skills, with only few exceptions, were consistently lower than the protégés' expectations of the mentors' skills both in the pre- and post-test ratings. For example, mentors' self-reported scores post-test were higher than 6.0 only for two skill items ("Establishing a trustful relationship" and "Acknowledging protégé's professional contribution"), while mean scores of protégés' expectations of mentors' skills were higher than 6.0 in eleven items. Both groups gave the highest post-test ratings to the "Establishing a trustful relationship" skill.

\section{Fear of Negative Evaluation (FNE)}

The Fear of Negative Evaluation (FNE) scale is used in clinical psychology to measure the likelihood of anxiety experienced by persons at the judgement of others in evaluative situations. It was described in "Measurement of Social-Evaluative Anxiety" by Watson and Friend in 1969. ${ }^{24}$ The authors developed the FNE alongside the Social Avoidance and Distress scale (SAD) in order to attain "greater predictive validity for specific situations" rather than more general assessment of different social situations that other scales generated. The Mentoring Program Workgroup considered using the FNE scale, among other anxiety assessments, because librarians were shown to suffer from FNE in a 2015 study by Crawford et al. ${ }^{25}$ The participants in the study reported through open-ended questions that FNE made them hesitant to take advantage of advancement opportunities.

The workgroup decided to use only the FNE to assess the protégé participants because it is best suited for measuring effects of anxiety in social situations while the SAD scale measures the avoidance of social situations. The results would also indicate whether the mentoring program was lowering the FNE barrier to 
seeking promotion and other advancements among the protégés. FNE is defined as "apprehension about others' evaluations, distress over their negative evaluations, avoidance of evaluative situations, and the expectation that others would evaluate oneself negatively." ${ }^{26}$ The FNE scale is available in the article and consists of 30 true/false questions. Watson and Friend crafted the questions to capture the targeted trait, "fear of loss of social approval," and its opposite, lack of anxiety about the evaluations of others, and not the presence of other traits such as the desire for positive evaluation. ${ }^{27}$ The authors cite the validity and homogeneity of the FNE scale in their article.

The Mentoring Program Workgroup administered the FNE survey to the protégés at the beginning and end of each year of the mentoring program. The researchers scored the responses according to the key found in the Watson and Friend article. ${ }^{28}$ Responses that were indicative of the construct "fear of negative evaluation" were given one point. The cumulative sum of the points indicated each participant's FNE score. The data were analyzed to find the mean, median, and mode among all participants for pre-tests and post-tests (Table 4).

The mean score for all pre-tests was 16.35 with a median of 15.50 . This was consistent with the mean of 16.72 among the 403 librarians assessed in the Crawford et al. study. ${ }^{29}$ The mean for all the post-tests was 15.60 with a median of 16.00 (Table 4). This represents a decrease in 0.75 points, or $4.6 \%$ in the mean score.

\section{Satisfaction Survey (End of Program Evaluation)}

The Mentoring Program Workgroup distributed End of Program Evaluation surveys at the Year-End Celebration during each of the three years of the mentoring program. The survey gauged participant satisfaction and collected feedback on areas of improvement and suggestions for future program years. This survey was developed by the University of Illinois at Chicago for a mentoring program developed for new clinical researchers. While there is no documentation of validity testing, the survey was available for reproduction, and the Mentoring Workgroup believed it to be a useful tool for measuring success. (Note: The survey is no longer available online, but the authors of this article printed a copy, which is available upon request.)

The tool consisted of a total of 28 questions: 22 in a Likert scale and six essay. Of the Likert-scaled questions, 10 focused on the features of the program, 10 on individual mentoring relationships, and two on the overall program experience. Participants responded on a five-option Likert scale ranging from "Strongly agree" to "Strongly disagree" for the program; an eight-option Likert scale for the relationship ranging from "Strongly agree" to "Strongly disagree," including a "not applicable" option, and a four-option scale for the overall program experience. The other six open-ended questions allowed for commentary on the scaled questions and inclusion of specific details about the mentoring relationship and experience.

The results of the survey discussed below are accumulated from two consecutive annual mentoring programs, FY 2016/17 and FY 2017/18. The results of the survey for the FY2015/16 cohort were not included in this report because of changes made to the survey instrument. The Mentoring Program Workgroup determined the mean, median, and mode for each of the questions answered by the mentors and protégés.

The mean satisfaction of the program ranged from 1.21 tol.74 on a scale of "Strongly agree" = 1 and "Strongly disagree" = 5 (Table 5). The highest responses were collected for "I would recommend the mentoring program to others" and the lowest for "The overall expected outcomes for the mentoring program were realistic."

The mean satisfaction of the mentoring relationships ranged from 1.75 to 2.90 on a scale of "Strongly agree" = 1 and "Strongly disagree" = 7 (Table 5). The highest responses were collected for "My mentor/protégé understood what I was saying and we had meaningful conversations" and the lowest for "My protégé shared concerns and asked good questions." 
The mean satisfaction scores for the program's overall experience was 1.29 on a scale of "Extremely satisfied" $=1$ and "Somewhat dissatisfied" $=4$. The mean effectiveness score was 1.71 on a scale of "Very effective" $=1$ and "Not effective at all" $=4$.

\section{Focus Group}

The Mentoring Program Workgroup decided, after three years of evaluating the mentoring program through the MCA, FNE, and satisfaction surveys, that conducting a qualitative assessment would enrich the data gathered from mentors and mentees. Qualitative methods offset the limitations of surveys, some of which are the inability to describe the nature of subjects' development over time or capture the social context of responses. ${ }^{30}$ The workgroup selected the focus group method to assess whether the mentoring program was meeting its goals. In addition to gathering a fuller picture of professional development of the participants, this method has the advantages of creating a group interaction in which ideas emerge that might be absent in individual interviews ${ }^{31}$ and getting feedback from multiple participants during one event.

The workgroup concentrated on the protégés in the library's mentoring program for the focus group conducted in August 2018. It was the first focus group the workgroup had conducted; therefore, the group wanted to learn the method and improve the approach before assessing the mentors. The study population consisted of librarians who had completed two years in the mentoring program and had experienced both dyad and group mentoring. The Mentoring Program Workgroup selected these criteria to assess subjects with enough experience in the program to discuss their development over time, and to gather their insights on both the dyad and group mentoring. Twelve librarians fit the criteria for the study population, but two who are members of the workgroup were excluded for lack of impartiality. The final study population included 10 potential subjects.

The Mentoring Program Workgroup made anonymity of the subjects a priority throughout the implementation of the protégé focus group in order to encourage free discussion of the mentoring program. While none of the workgroup members were supervisors of the protégés, the workgroup did not want the protégés to curtail their responses from any fear of negative impacts. The UNT IRB approved the study, with special measures to protect the anonymity of the participants. The workgroup enlisted the help of a graduate student employed by the library, who had experience in conducting focus groups. He became the sole contact for the subjects throughout the process. The student sent an invitation email to the 10 librarians, and assigned random numbers to the five who agreed to participate. The numbers were used to identify the subjects from that point forward.

The focus group arrangements all worked toward making an environment where the protégés would feel comfortable sharing their honest opinions of the mentoring program. The workgroup asked an education professor experienced in qualitative assessment, who did not know any of the participants, to be the facilitator for the focus group. The conference room scheduled for the focus group was located in an academic building out of sight of the library. The setup time for the conference room and the arrival time of the participants were staggered to prevent the researchers from seeing the participants. The facilitator asked prepared questions written by the researchers, which were formulated along guidelines from Liamputtong. ${ }^{32}$ The graduate student took notes during the two-hour discussion, identifying the speakers by their random number assignments, and made an audio recording of the event. During the focus group, the facilitator asked an additional follow-up question, which is listed with the prepared questions in Appendix 1.

The analysis of the focus group responses started with the transcription of the notes and audio recording. The graduate student transcribed the audio recording verbatim and included pauses, exclamations, laughter, and other expressions that lent context to the text. ${ }^{33}$ Three researchers conducted a thematic analysis of the transcription, as described by Liamputtong. Initially all three read the transcription and identified themes. Then the common themes were used by one researcher to code the subjects' discussion in NVivo 12 .

The focus group's discussion suggests that the mentoring program is progressing towards meeting its goals and needs improvements. One of the program's goals is to increase the confidence of the protégés. The junior 
librarians have appreciated mentors who outline the steps needed to advance from a new librarian to one ready for promotion. Mentors also clarified the actual promotion application process and the types of documentation that should be in a dossier. Through group mentoring, the protégés were able to meet members of the Personnel Affairs Committee and get feedback on their curriculum vitae. All of these activities have made the protégés more confident about what they need to accomplish for their first promotion to associate librarian.

Another goal of the mentoring program is to improve mentoring competencies. According to the protégés, their mentors and peers have strong psychosocial skills. The protégés mentioned repeatedly that they value the confidentiality provided to them both through the dyad and group mentoring. The mentors and peers are good listeners with whom they can discuss work and professional concerns without being judged or labeled as having a bad attitude. All of the protégés expressed a sense of belonging because their mentors and peers have shared their own struggles with feelings of inadequacy and with finding suitable solutions to career problems.

While performing well in psychosocial competencies, the protégés' comments suggest the mentors need to improve in the areas of creating and aligning expectations and guiding professional development. Most of the protégés in this focus group had experienced a more informal relationship with their mentors, with few structured activities and objectives for professional development beyond promotion preparation. It was clear to the protégés who participated in the first year of the mentoring program that the mentors were still in training.

The protégés had helpful suggestions to improve the group mentoring, which they value for coordinated activities and camaraderie. They recommended making the names of the mentoring groups match their purposes. UNT's mascot is the eagle and the incorporation of eagle references in names muddied the intent of the groups. The protégés also favored having the group mentoring in cohorts, rather than changing the group composition every year, in order to maintain an environment where they feel comfortable sharing accomplishments and concerns.

Overall, the protégés are pleased with the mentoring program and want to see it continue. They mentioned multiple times that the program gives them a broader perspective of the library organization and of librarianship, showing them different solutions to work challenges and a variety of career opportunities. The protégés all agreed the library administration should sustain the mentoring program with funding. Finally, they were also in agreement they would all like to serve as mentors in the future based on their positive experiences.

\section{Discussion and Conclusion}

Because the UNT Libraries had never had a formal mentoring program for its librarian faculty members, the goal of the initial programs was to develop the librarianship skills of the new librarians, as well as the mentoring skills of the established librarians. Assessment of these goals was planned with the initial pilot of the program in FY 2015/16 using the three surveys described earlier. These surveys, developed from outside of the field of librarianship, were selected largely because there were so few options available from within our field. Most reports of mentoring programs in library literature did not include any assessment at all. Of those that did, the primary method was satisfaction surveys, which were not tested for validity, nor even included in the published reports.

The original Mentoring Program Workgroup wanted to establish a model of continuous assessment that could be used over the long term. This is because the number of individuals participating each year would be limited; accumulating responses over the years of the program will enable the workgroup to have more statistically valid analyses of effectiveness. Without these regular assessment efforts, the Mentoring Program Workgroup would have little basis on which to plan new programs and make improvements. 
It became apparent, however, that quantitative measures of assessment alone have not provided enough information to improve the program. The workgroup wanted to learn more about how the participants felt about the program, their impressions of one-on-one mentoring, and their viewpoints of the quality of the program. Towards that end, the workgroup pursued a qualitative method, taking extraordinary efforts to reduce bias and protect anonymity by having a moderator from outside the library and conducting the focus group session in another building.

The results of the focus group support the results of the three surveys given to mentors and protégés. When the mentors took the post-test MCA, they rated themselves highest on the skill, "Establishing a trustful relationship." All protégés in the focus group agreed their mentors and peers had been successful in creating a trustful environment by providing confidentiality and strong listening skills. The protégés' comments were also consistent with the lowest mean score in the End of Program Evaluation, "My mentor offered guidance and knowledge." The protégés observed the mentors were helpful in promotion preparation, but beyond that area, needed to be more structured in providing guidance for a career trajectory. The confidence of the protégés increased regarding their upcoming promotion applications, which aligns with the decrease in the post-test score of the FNE.

Through these assessment measures, the Mentoring Program Workgroup has documented measures of success in meeting the goals of preparing new librarians for academic librarianship and the rigors of promotion. Their self-confidence has improved, as documented by the reduced scores of the FNE scale, as well as by their responses to both the open-ended questions of the evaluation survey and within the focus group. While there is documented improvement in the mentors' self-assessment of skills through the MCA scores, the responses to the open-ended questions and the focus group responses indicate that more effort is needed to improve mentorship skills.

There are a few limitations of our assessment method, notably the inability to analyze results at the individual and dyad levels, the difficulty of improving response rates, and the lack of a measure of ultimate impact on the protégés. In the first year, there was an attempt to track individual pre- and post-program responses to the MCA while maintaining anonymity, but it was not successful. Participants were asked to put in the last four digits of their phone number, but some did not include this data and others entered different numbers in the pre- and post-tests. For later iterations, the surveys were sent anonymously without any tracking capability. The Mentoring Program Workgroup has since received the UNT IRB's approval to change the survey from anonymous to confidential, enabling future analyses at group, individual, and dyad levels.

The response rates have only been modest since the first year, even with incentives. The workgroup has received approval to use additional incentives (five-dollar vouchers for the library coffee shop for each survey completed), which are included in the program's FY 2018/19 budget. The Mentoring Program Workgroup will track response rates to determine the value of this incentive program.

Most importantly, the above assessments do not measure the ultimate goal of the program, which is for the librarians who participate to be successful in their careers. While increasing confidence is a step towards that, the workgroup currently has no valid measure associated with this goal. Such an outcome is difficult to measure because the meaning of "successful in their careers" is ambiguous. Many factors contribute to such an outcome, and it would usually occur a long time after the end of the formal program. With these difficulties in mind, the Mentoring Program Workgroup will be reviewing optimal measures, including, but not limited to, time to promotion, annual evaluation scores, participation in other career development activities, and overall career satisfaction.

-Copyright 2019 Karen Harker, Setareh Keshmiripour, Marcia McIntosh, Erin O’Toole, and Catherine Sassen 


\section{Endnotes}

1. Lorna Gail Lunsford, A Handbook for Managing Mentoring Programs: Starting, Supporting and Sustaining Effective Mentoring (London: Routledge, 2016), 145.

2. Carole J. Bland et al., Faculty Success through Mentoring: A Guide for Mentors, Mentees, and Leaders (Lanham, MD: Rowman \& Littlefield, 2011), 42.

3. Susan R. Hines, "Investigating Faculty Development Program Assessment Practices: What's Being Done and How Can It Be Improved?” Journal of Faculty Development 23, no. 3 (2009): 7.

4. Mandi Goodsett and Andrew Walsh, "Building a Strong Foundation: Mentoring Programs for Novice Tenure-Track Librarians in Academic Libraries,” College \& Research Libraries 76, no. 7 (Nov 1, 2015): 914-933, https://doi.org/10.5860/crl.76.7.914.

5. Diane Lorenzetti and Susan Powelson, "A Scoping Review of Mentoring Programs for Academic Librarians,” The Journal of Academic Librarianship 41, no. 2 (March 2015): 186-196, https://doi.org/10.1016/j.acalib.2014.12.001.

6. Lorenzetti and Powelson, "A Scoping Review."

7. Floyd Fowler, "Designing Questions to Be Good Measures," in Survey Research Methods, 4th ed. (Thousand Oaks, California: SAGE Publications, Inc., 2009), 86-113.

8. Jill Cirasella and Maura Smale, "Peers Don't Let Peers Perish: Encouraging Research and Scholarship among Junior Library Faculty," Collaborative Librarianship 3, no. 2 (2011): 98-109, https://digitalcommons.du.edu/collaborativelibrarianship/vol3/iss2/5.

9. Richard Sapon-White, Valery King, and Anne Christie, "Supporting a Culture of Scholarship for Academic Librarians," portal: Libraries \& the Academy 4, no. 3 (2004): 407-422, https://doi.org/ 10.1353/pla.2004.0044.

10. Lorenzetti and Powelson, "A Scoping Review."

11. Lois Kuyper-Rushing, "A Formal Mentoring Program in a University Library: Components of a Successful Experiment," The Journal of Academic Librarianship 27, no. 6 (2001): 440-446, https://doi.org/10.1016/S0099-1333(01)00258-0.

12. Kuyper-Rushing, "A Formal Mentoring Program in a University Library."

13. Eileen Bosch et al., "The Resource Team Model: An Innovative Mentoring Program for Academic Librarians," New Review of Academic Librarianship 16, no. 1 (March 2, 2010): 57-74, https://doi.org.10.1080/13614530903584305.

14. V. Clark and N. Ivankova, "Why Use Mixed Methods Research? Identifying Rationales for Mixing Methods," in Mixed Methods Research: A Guide to the Field (Thousand Oaks, California: SAGE Publications, Inc, 2016), 79-104.

15. Lorenzetti and Powelson, "A Scoping Review."

16. Diana Farmer, Marcia Stockham, and Alice Trussell, "Revitalizing a Mentoring Program for Academic Librarians," College \& Research Libraries 70, no. 1 (January 1, 2009): 8-24, https://doi.org/10.5860/0700008.

17. Goodsett and Walsh, "Building a Strong Foundation" and Toni Anaya and Charlene Maxey-Harris, SPEC Kit 356: Diversity and Inclusion (Washington, DC: Association of Research Libraries, 2017), 1-7.

18. Marni Harrington and Elizabeth Marshall, "Analyses of Mentoring Expectations, Activities, and Support in Canadian Academic Libraries," College \& Research Libraries 75, no. 6 (Nov 1, 2014): 763-790, https://doi.org/10.5860/crl.75.6.763; Tochukwu Nwankwo, Chika Ike, and Chinedu Anozie, "Mentoring of Young Librarians in South East Nigeria for Improved Research and Scholarly Publications," Library Management 38, no. 8/9 (November 14, 2017): 455-476, https://doi.org/10.1108/LM-11-2016-0083; and Amy Vilz and Molly Poremski, "Perceptions of Support Systems for Tenure-Track Librarians," College $\boldsymbol{\varepsilon}$ Undergraduate Libraries 22, no. 2 (April 3, 2015): 149-166, https://doi.org/10.1080/10691316.2014.924845.

19. Farmer, Stockham and Trussell, "Revitalizing a Mentoring Program."

20. Joanne Colley, Connie Capers Thorson, and C. Capers Thorson, "Mentoring along the Tenure Track," College and Research Libraries News 51, no. 4 (1990), 
https://search.proquest.com/docview/1307514403; Goodsett and Walsh, "Building a Strong Foundation"; and Harrington and Marshall, "Analyses of Mentoring Expectations."

21. Michael Fleming et al., "The Mentoring Competency Assessment: Validation of a New Instrument to Evaluate Skills of Research Mentors," Academic Medicine 88 no. 7 (2013): 1002-1008, https://www.ncbi.nlm.nih.gov/pubmed/23702534.

22. Fleming et al., "The Mentoring Competency Assessment."

23. University of Wisconsin Institute for Clinical and Translational Research, "Mentor Evaluation Form Examples," 2018, https://ictr.wisc.edu/mentoring/mentor-evaluation-form-examples.

24. David Watson and Ronald Friend, "Measurement of Social-Evaluative Anxiety," Journal of Consulting and Clinical Psychology 33, no. 4 (1969): 448-457.

25. Laurel Crawford et al., "Fear of Negative Evaluation: Differences amongst Librarians," Library Leadership and Management 29, no. 3 (2015).

26. Watson and Friend, "Measurement of Social-Evaluative Anxiety," 449.

27. Watson and Friend, 449.

28. Watson and Friend, 450.

29. Crawford et al., "Fear of Negative Evaluation."

30. Clark and Ivankova, "Why Use Mixed Methods Research?"; David Morgan, "Research Design and Research Methods," in Integrating Qualitative and Quantitative Methods: A Pragmatic Approach (55 City Road, London: SAGE Publications, Inc., 2014), 45-62.

31. Pranee Liamputtong, "Theory and Ethics," in Focus Group Methodology: Principles and Practice (London: SAGE Publications, 2011), 15-30.

32. Liamputtong, "Conducting Focus Groups and Practicalities," 71-86.

33. Liamputtong, "Managing and Making Sense of Focus Group Data," 165-181. 
Table 1. Demographics of Mentoring Program Participants

\begin{tabular}{|l|l|l|l|l|l|l|}
\hline & \multicolumn{2}{l}{ FY 2015/16 } & FY 2016/17 & \multicolumn{2}{l|}{ FY 2017/18 } \\
\hline & Protégés & Mentors & Protégés & Mentors & Protégés & Mentors \\
\hline Total \# of individuals & 5 & 4 & 15 & 14 & 11 & 13 \\
\hline By Gender (f/m) & $3 / 2$ & $3 / 1$ & $10 / 5$ & $12 / 2$ & $8 / 3$ & $8 / 5$ \\
\hline By minority status* (y/n) & $1 / 4$ & $1 / 3$ & $2 / 13$ & $1 / 13$ & $2 / 9$ & $1 / 12$ \\
\hline
\end{tabular}

* Member of any group that is not white, non-Hispanic, cisgender

Table 2. Baseline Mean Scores for the 25 Skills Evaluated by the Mentoring Competency Assessment, as Rated by Mentors in FY 2015/16-FY 2017/18

Skills by competency

Maintaining effective communication

Active listening

Providing constructive feedback

Establishing a trustful relationship

Identifying and accommodating communication styles

Applying strategies to improve communication

Coordinating effectively with supervisor(s)

\section{Aligning expectations}

\begin{tabular}{|c|c|c|c|c|c|c|}
\hline Setting clear mentoring relationship expectations & 4.75 & 5 & 1.07 & 5.53 & 6 & 1.03 \\
\hline Aligning expectations & 4.90 & 5 & 0.97 & 5.29 & 5 & 1.14 \\
\hline Considering mentor-protégés differences & 5.20 & 6 & 1.01 & 5.76 & 6 & 1.27 \\
\hline Setting relationship goals & 5.35 & 6 & 1.09 & 5.18 & 6 & 0.89 \\
\hline Developing strategies to achieve goals & 5.40 & 6 & 0.94 & 5.59 & 6 & 0.92 \\
\hline \multicolumn{7}{|l|}{ Assessing understanding } \\
\hline Assessing protégé's knowledge & 5.15 & 6 & 1.14 & 5.35 & 6 & 1.32 \\
\hline Estimating protégé's ability & 5.15 & 5 & 1.27 & 5.12 & 5 & 1.09 \\
\hline Enhancing protégé's knowledge and abilities & 5.35 & 6 & 1.04 & 5.53 & 6 & 1.04 \\
\hline \multicolumn{7}{|l|}{ Fostering independence } \\
\hline Motivating protégé & 4.85 & 5 & 1.14 & 5.06 & 5 & 0.93 \\
\hline
\end{tabular}




\begin{tabular}{|c|c|c|c|c|c|c|}
\hline Building protégé's confidence & 5.20 & 6 & 1.15 & 5.53 & 6 & 0.83 \\
\hline Stimulating protégé's creativity & 5.05 & 5 & 1.19 & 4.88 & 5 & 1.00 \\
\hline Acknowledging protégé's professional contribution & 5.85 & 6 & 0.93 & 6.12 & 6 & 0.91 \\
\hline Negotiating a path to professional independence & 4.80 & 5 & 1.44 & 5.35 & 5 & 0.79 \\
\hline \multicolumn{7}{|l|}{ Addressing diversity } \\
\hline Accounting for biases and prejudices & 5.15 & 6 & 1.09 & 5.59 & 6 & 1.02 \\
\hline Accounting for mentor-protégé differences & 5.45 & 6 & 1.70 & 5.29 & 6 & 1.30 \\
\hline \multicolumn{7}{|l|}{ Promoting professional development } \\
\hline Helping network effectively & 4.80 & 5 & 1.51 & 5.00 & 5 & 1.15 \\
\hline Helping protégé set career goals & 5.25 & 6 & 1.25 & 5.29 & 5 & 0.91 \\
\hline Helping protégé maintain work-life balance & 5.10 & 6 & 1.41 & 5.24 & 5 & 1.33 \\
\hline Understanding impact as a role model & 4.85 & 5 & 1.39 & 5.41 & 6 & 0.93 \\
\hline
\end{tabular}

Table 3. Baseline Mean Scores for the 25 Skills Evaluated by the Mentoring Competency Assessment, as Rated by Protégés in FY 2015/16-FY 2017/18

\begin{tabular}{|c|l|l|l|l|l|l|}
\hline \multirow{2}{*}{ Skills by competency } & \multicolumn{2}{l}{ Pre-Test (N = 25) } & \multicolumn{2}{l|}{ Post-Test (N = 20) } \\
\cline { 2 - 7 } & Mean & Median & SD & Mean & Median & SD \\
\hline Maintaining effective communication & & & & & & \\
\hline Active listening & 6.20 & 7 & 1.08 & 6.30 & 6 & 0.73 \\
\hline Providing constructive feedback & 6.44 & 7 & 0.71 & 6.50 & 7 & 0.61 \\
\hline Establishing a trustful relationship & 6.48 & 7 & 0.71 & 6.80 & 7 & 0.41 \\
\hline Identifying and accommodating communication styles & 6.00 & 6 & 0.82 & 6.15 & 6 & 0.81 \\
\hline Applying strategies to improve communication & 5.96 & 6 & 0.93 & 6.10 & 6 & 0.64 \\
\hline Coordinating effectively with supervisor(s) & 5.83 & 6 & 1.37 & 5.89 & 7 & 1.32 \\
\hline Aligning expectations & & & & & & \\
\hline Setting clear mentoring relationship expectations & 6.24 & 6 & 0.78 & 5.70 & 6 & 1.03 \\
\hline Aligning expectations & 6.04 & 6 & 0.68 & 5.65 & 6 & 1.14 \\
\hline Considering mentor-protégés differences & 5.68 & 6 & 0.99 & 5.65 & 6 & 1.27 \\
\hline Setting relationship goals & 6.16 & 6 & 0.99 & 5.80 & 6 & 0.89 \\
\hline
\end{tabular}




\begin{tabular}{|c|c|c|c|c|c|c|}
\hline Developing strategies to achieve goals & 6.56 & 7 & 0.71 & 6.00 & 6 & 0.92 \\
\hline \multicolumn{7}{|l|}{ Assessing understanding } \\
\hline Assessing protégé's knowledge & 5.68 & 6 & 1.14 & 5.55 & 6 & 1.32 \\
\hline Estimating protégé's ability & 6.00 & 6 & 1.08 & 5.85 & 6 & 1.09 \\
\hline Enhancing protégé's knowledge and abilities & 6.38 & 7 & 0.88 & 6.15 & 6 & 1.04 \\
\hline \multicolumn{7}{|l|}{ Fostering independence } \\
\hline Motivating protégé & 5.48 & 5 & 1.16 & 5.85 & 6 & 0.93 \\
\hline Building protégé's confidence & 5.68 & 6 & 1.03 & 6.05 & 6 & 0.83 \\
\hline Stimulating protégé's creativity & 6.00 & 6 & 0.91 & 5.95 & 6 & 1.00 \\
\hline Acknowledging protégé's professional contribution & 5.40 & 5 & 1.08 & 6.10 & 6 & 0.91 \\
\hline Negotiating a path to professional independence & 5.92 & 6 & 1.38 & 6.10 & 6 & 0.79 \\
\hline \multicolumn{7}{|l|}{ Addressing diversity } \\
\hline Accounting for biases and prejudices & 5.52 & 6 & 1.00 & 5.58 & 5 & 1.02 \\
\hline Accounting for mentor-protégé differences & 5.48 & 5 & 1.16 & 5.70 & 6 & 1.30 \\
\hline \multicolumn{7}{|l|}{ Promoting professional development } \\
\hline Helping network effectively & 6.16 & 6 & 1.03 & 5.95 & 6 & 1.15 \\
\hline Helping protégé set career goals & 6.12 & 6 & 0.83 & 6.10 & 6 & 0.91 \\
\hline Helping protégé maintain work-life balance & 5.28 & 5 & 1.43 & 5.74 & 6 & 1.33 \\
\hline Understanding impact as a role model & 5.64 & 6 & 1.08 & 5.85 & 6 & 0.93 \\
\hline
\end{tabular}

Table 4. FNE Score Analysis of Protégés in FY 2015/16-FY 2017/18

\begin{tabular}{|l|l|l|l|}
\hline & Mean & Median & Mode \\
\hline Pre-Test $(\mathrm{n}=10)$ & 16.35 & 15.50 & 19 \\
\hline Post-Test $(\mathrm{n}=10)$ & 15.60 & 16.00 & 25 \\
\hline
\end{tabular}


Table 5. Results of the End of Program Evaluation Survey FY 2016/17-FY 2017/18

\begin{tabular}{|c|c|c|c|}
\hline Evaluation Questions & Mean & Median & Mode \\
\hline \multicolumn{4}{|l|}{ The Mentoring Program ( $1=$ Strongly Agree, 5 = Strongly Disagree) } \\
\hline The kick-off event was informative and a beneficial way to start the program. & 1.64 & 2 & 1 \\
\hline The goals and objectives of the mentoring program were clearly defined. & 1.71 & 2 & 2 \\
\hline $\begin{array}{l}\text { The structure of the program made it easy to perform my role in this } \\
\text { relationship. }\end{array}$ & 1.43 & 1 & 1 \\
\hline I felt supported by the mentoring committee. & 1.39 & 1 & 1 \\
\hline The time commitment for each interaction was just right. & 1.71 & 1.5 & 1 \\
\hline I felt the match between my mentoring partner and I was a good fit. & 1.32 & 1 & 1 \\
\hline I believe the program will benefit my professional development. & 1.46 & 1 & 1 \\
\hline The overall expected outcomes for the mentoring program were realistic. & 1.74 & 1 & 1 \\
\hline Realistic Expectations & 1.43 & 1 & 1 \\
\hline I would recommend the mentoring program to others. & 1.21 & 1 & 1 \\
\hline \multicolumn{4}{|l|}{ Mentoring Relationship ( $1=$ Strongly Agree, 7 = Strongly Disagree) } \\
\hline The match between my mentoring partner and I met my needs. & 1.93 & 1.5 & 1 \\
\hline We met regularly. & 1.89 & 2 & 2 \\
\hline We came prepared to use the time effectively. & 2.21 & 2 & 2 \\
\hline We were confident about what to do when we started. & 1.93 & 2 & 1 \\
\hline $\begin{array}{l}\text { My mentor/protégé understood what I was saying and we had meaningful } \\
\text { conversations. }\end{array}$ & 1.75 & 1 & 1 \\
\hline I experienced learning and growth during the process. & 1.89 & 1 & 1 \\
\hline My mentor offered guidance and knowledge. & 2.36 & 1 & 1 \\
\hline My protégé shared concerns and asked good questions. & 2.90 & 2 & 2 \\
\hline My mentor/protégé enlightened me. & 1.86 & 2 & 1 \\
\hline This relationship will continue beyond the formal process. & 1.82 & 1.5 & 1 \\
\hline \multicolumn{4}{|l|}{$\begin{array}{l}\text { Overall Experience ( } 1=\text { Extremely satisfied/Very effective, } 4 \text { = Somewhat } \\
\text { dissatisfied/Not at all effective) }\end{array}$} \\
\hline How satisfied were you with your experience as a mentor/protégé? & 1.29 & 1 & 1 \\
\hline How effective was the overall program? & 1.71 & 2 & 2 \\
\hline
\end{tabular}




\section{Appendix 1: Questions for Protégé Focus Group}

Introduction: Would you tell me about one highlight of your experience in the mentoring program?

Transition: How did you interact with your mentor?

Focus: How has the one-on-one mentoring influenced your job and development as a professional librarian?

Focus: How has the group mentoring influenced your job and development as a professional librarian?

Focus: How has the mentoring program impacted your attitude towards your job and librarianship in general?

Follow up if needed: How has your confidence level in performing your job and contributing to your profession changed?

*Follow up if needed: How has the program affected your sense of belonging in the UNT Libraries and professional communities?

Focus: How could the mentoring program be improved to increase participation of new librarians in the future?

Focus: What have you valued the most in your experience in the mentoring program?

**Concluding: Would any of you consider being a mentor in this program if you have the opportunity? If so, why would you choose to mentor?

Concluding: Is there anything else you think we should discuss about the mentoring program, but haven't?

*The facilitator did not ask this question because it had already been answered.

**The facilitator added this question. 